fleeting, rapidly variable, character of the defects typical of this disease is absent. Ophthalmoscopic evidence is of little determining value as the fundus may be normal or the disc may show various degrees of swelling or moderate pallor but neither complete whiteness nor persistent choked disc of intracranial pressure type occurs. In localized syphilitic basal meningitis bitemporal hemianopia with headache may be occasionally the only or almost the only symptom, but the field changes are grosser and other evidence is practically always forthcoming.

When the field defects are homonymous it is necessary to exclude a suprageniculate lesion. The presence of incongruity is of assistance here and also the character of the field defects; for suprageniculate lesions, apart from injuries and certain vascular conditions in the visual cortex, very rarely if ever cause central defects especially of a variable character. Apart from this the diagnosis from tumour and syphilis affecting the tract is based on the same considerations as in the case of the chiasma.

Prognosis and Treatment.-As in retrobulbar neuritis of the usual type the prognosis as regards recovery of sight appears to be excellent but should be guarded in respect of later development of nervous disease. Similarly, no special form of treatment is indicated.

\title{
REFERENCES
}

1. Roenne-Klin. Monatsbl.f. Augenheilk., II. S. 446, 1912.

2. Idem.-Ibid., II. S. 68, 1915.

3. Traquair.-Brit. Jl. of Ophthal., April, June, 1917.

4. Idem.-Trans. Ophthal. Soc. U.K., Vol. XLIII, p. 480, 1923.

\section{TWO CASES OF NON-TRAUMATIC CYSTS OF THE ANTERIOR CHAMBER}

\author{
BY \\ D. J. WOOD \\ CAPE TOWN
}

Although I have found several records in the Transactions of the Ophthalmological Society of clear cysts of the anterior chamber, they are very uncommon, and until two years ago I had never seen a case. My excuse for describing these two cases is that I have been able to examine one of them with the slit-lamp, and am able to describe their appearance when magnified.

Both cases occurred in girls, both were in the right eye, and both in the same place, the lower inner quadrant. Any history of injury was definitely denied, and careful slit-lamp examination of the cornea and neighbourhood showed no trace of it. Both 


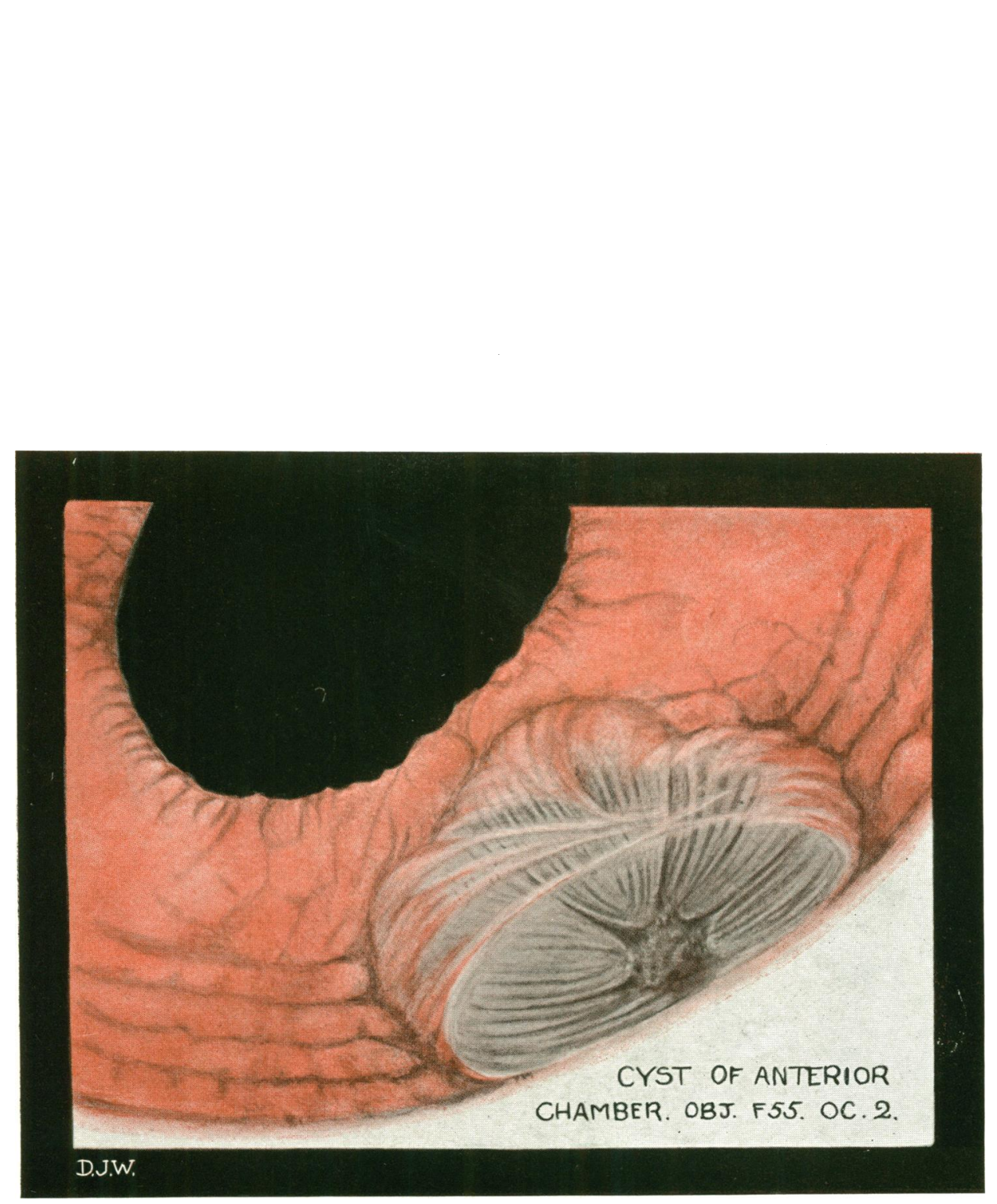

$\overrightarrow{0}$

$\overrightarrow{\vec{\omega}}$ 
girls were in good health; the younger was a little defective mentally. The younger girl, Eda B., an Italian, aged 11 years, was seen in May, 1922, and the elder girl Miss R, aged 19 years, came a week later. The latter only noticed the cyst when it began to distort the margin of her pupil, viz., for about two years; the younger case had shown the peculiarity for five years; in each case there had been only a slight increase in size.

The naked eye appearance was very similar in the two cases and a photograph of the elder serves for each. The lower inner quadrant of the anterior chamber was occupied by a transparent

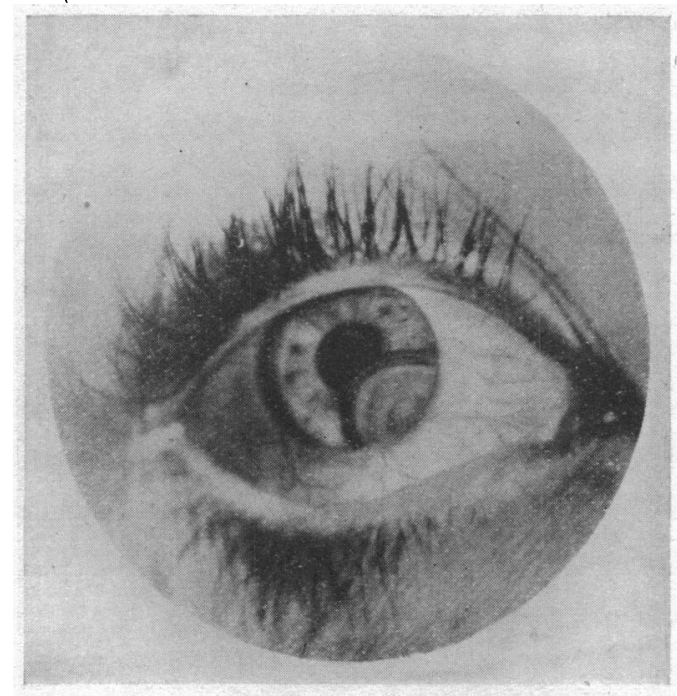

Cyst of Anterior Chamber. Miss J. R. July, 1922.

rounded cyst, reaching to and flattening the edge of the pupil, and bordered there by concentric curves of iris tissue. There was no visible structure in the slate-grey background, except a darker spot at the lowest part. There was no light reflex through any part; vision was very good; there was no pain or increase of tension.

As the elder girl considered the condition a deformity I decided to rupture the cyst. This was done by a discission needle, though the cyst wall was tougher than I expected. The cyst collapsed at once, and I was able to push the iris stroma down over the background so that nothing was visibly wrong when the pupil was dilated, and very little when it was not. The cyst had split the iris into its two layers, the uvea forming its back, the stroma being displaced up towards the pupil. 
For six weeks this state of affairs lasted, and then quite suddenly the cyst re-appeared in its former size. As I had not at that time received my slit-lamp, and assuming that the cyst was liable to cause trouble I attempted to remove it. An incision through the limbus at the site of the cyst resulted in collapse, but not prolapse, and it was impossible to see the cyst wall. I pulled out something but it brought out the iris stroma, which had to be cut off, while

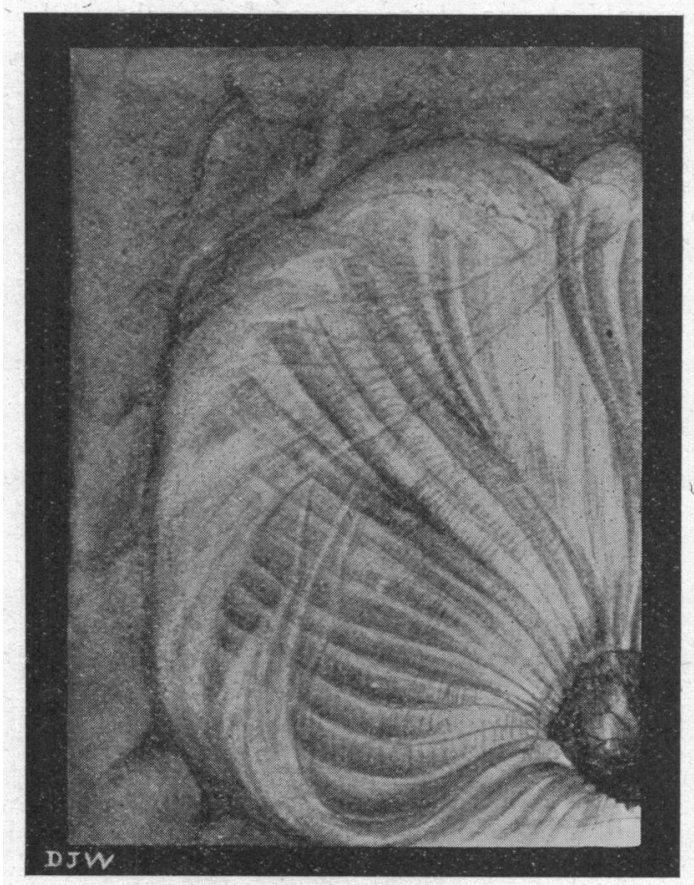

Detail of Cyst. Obj. A2. Oc. 2.

a part of the uvea followed, and had to be also removed, mainly as debris. A small coloboma was left but vision was not impaired.

As others have found, the fragment was so tangled up that the relation of parts was difficult to follow. The cyst wall is a clear firm membrane staining red with van Gieson's stain, and is covered by a layer of cells which, though they are not regularly hexagonal, resemble closely those on Descemet's membrane, both in size, and in their large nuclei. They appear in all parts, however, of the sections except in the uveal tissue, but do not form layers. There is no trace of epithelial debris. From October, 1922 , no return was visible till somewhere early in 1924. Seen in May there was a definite return. Most of the cyst was still 
covered by iris, and the small coloboma was obliterated. No discomfort and good sight.

After the discission of the cyst in this patient, I saw the younger girl, August, 1922, and to my surprise the cyst had vanished, the only trace being a small dark spot in the extreme angle of the anterior chamber. There had been no injury to the eye, nor was the patient aware when the cyst had ruptured. The pupil was practically round. In November, 1923, the patient was got back for examination with the slit-lamp, and I found the cyst had returned, and looked just as it did when first seen.

The drawings give but a poor idea of the beauty of the cyst as seen under slit-lamp illumination. The details were very fine, the appearance altered according to the angle of illumination, and the patient was extremely unsteady.

The cyst had intruded itself between the uvea and the stroma of the iris, the former being the posterior wall, the latter the back part of the roof. The front is formed by the cornea which showed a fine stippling, probably endothelial, and a few lines like wrinkles, possibly produced when the cyst was smaller.

The posterior wall shows a beautifully scalloped structure. There are six main divisions separated by well-defined ridges, making the cyst look like a parachute rather than a balloon. Each segment is in turn divided by finer, closely set, radiating ridges, with sharp edges and rounded grooves between. These grooves are covered with fine close transverse lines.

All the ridges start abruptly from a small area of flat uveal tissue in the centre of the lowest part of the cyst, and extend upward as far as where the cyst separates from the iris. From this point the cyst is smooth and rounded, and passes over to the cornea. The part next the iris is lightly pigmented by iris tissue drawn out over it and ending in a line or wrinkle on the cyst roof. The pigment stops where the roof reaches the cornea. The centre of the lowest part of the posterior wall consists of a rounded area of uvea, darkly pigmented below, stippled with white above. On it can be seen fine radial vessels which branch towards the pupil, and which can be traced for a short distance over the posterior wall.

There is thus a suggestion that the ridges are due to the resistance offered by blood-vessels, larger or smaller. It is at least not clear how otherwise they could be formed.

The appearance also suggests that the cyst must have arisen from the very angle of the anterior chamber, probably from the pectinate ligament. There is no indication that it has been formed by obstruction of iris crypts, as it is behind the stroma. The whole appearance is also quite against its being due to traumatism 
The slit-lamp indicates clearly the reason for failure to remove the cyst without the iris ; even on the roof the connection is close, and though it is impossible to see the true wall of the cyst except on the roof, yet it must undoubtedly extend all over the back and front.

In spite of my first failure I think that extensive rupture of the cyst wall, either by free discission or by the removal of a part of the cyst roof would be a better treatment than attempts at total removal. With a more complete idea of the structure of the cysts, such as one gains from examination with the slit-lamp, it would seem impossible to remove the whole without a very extensive operation, and perhaps not even then. How far these cysts do any harm is not clear. They grow slowly, and sometimes at all events rupture spontaneously. I have not been able to find records of the subsequent histories of the recorded cases, and it would seem possible that some returned slowly without causing symptoms.

\section{REFERENCES}

Treacher Collins.- "Cysts of Iris." Roy. Lond. Ophthal. Hosp. Rep., Vol. XIII.

Benson.-Trans. Ophthal. Soc. U.K., Vol. IX, p. 56.

Morton.-Trans. Ophthal. Soc. U.K., Vol. XIII, p. 58.

Juler.-Trans. Ophthal. Soc. U.K,, Vol. XIII, p. 60.

Pisani.-Trans. Ophthal. Soc. U.K., Vol. XXXII, p. 56.

Whitehead.-Trans. Ophthal. Soc. U.K., Vol. XXIV, p. 78.

Mentioned in the above :

Schmidt-Rimpler-Arch. f. Ophthal., Vol. XXXV.

Nadal.-A rch. d'Ophtal., 1911.

Juselius. - Kli». Monatsbl.f. Augenheilk., September, 1908.

Gallemaerts.-Arch. d'Ophtal., 1907.

\section{CYST OF THE IRIS}

BY

MAJOR R. E. WRIGHT, I.M.S.

SUPERINTENDENT, GOVERNMENT: OPHTHALMIC HOSPITAL, MADRAS

T., Hindu female, aged 20 years, came to Hospital on July 31 , 1924, complaining of pain and dimness of vision in the left eye. On inquiry it appeared that she had a defect of sight with nystagmus from childhood. Twenty days before attending she sustained an injury, with the finger nail, in the left eye, which was attended by slight bleeding. The vision of the left eye was fingers at 4 metres, not improved with lenses; that of the right eye $6 / 60$, with a plus $4.5 \mathrm{sph} .=6 / 36$, no improvement with cylinders. On inspection of the left eye there appeared to be a dull haze in the inferior nasal quadrant of the cornea like a deep keratitis. There was increased vascularity at the limbus in this region and for some distance on 